\title{
Systematics of the genus Cnesterodon Garman, 1895 (Cyprinodontiformes: Poeciliidae: Poeciliinae)
}

\author{
Paulo H. F. Lucinda
}

A phylogenetic hypothesis of relationships is proposed for the species of Cnesterodon. A series of derived features supports the monophyly of the genus and infrageneric clades. The genus Cnesterodon is revised, with Gulapinnus considered a junior synonym. A lectotype is designated for Poecilia decemmaculata Jenyns. Nine species of Cnesterodon are recognized: C. decemmaculatus, C. carnegiei, C. brevirostratus, C. septentrionalis, C.omorgmatos, C. hypselurus, C. raddai, a new species from the rio Ribeira de Iguape, described herein, and a new species from the Rio Grande do Sul, being described by in a separate paper. Diagnoses and distribution ranges are provided for each species as well as a key to identification of the species.

Uma hipótese de relações filogenéticas é proposta para as espécies de Cnesterodon. Uma série de caracteres derivados corrobora o monofiletismo do gênero e dos clados infragenéricos. O gênero Cnesterodon é revisado, com Gulapinnus considerado um sinônimo júnior. Um lectótipo para Poecilia decemmaculata Jenyns é designado. Nove espécies de Cnesterodon são reconhecidas: C. decemmaculatus, C. carnegiei, C. brevirostratus, C. septentrionalis, C. omorgmatos, C. hypselurus, $C$. raddai, uma nova espécie do rio Ribeira de Iguape, aqui descrita, e uma nova espécie do Rio Grande do Sul, sendo descrita em outro trabalho. Diagnoses e distribuição são apresentadas para cada espécies bem como uma chave para a identificação das espécies.

Key-words: Neotropical Ichthyofauna, taxonomy, phylogeny, live-bearing killifishes.

\section{Introduction}

The genus Cnesterodon Garman, 1895 comprises small poeciliids distributed in southern South America. Cnesterodon species live in the upper rio Araguaia basin, the Paraná-Paraguay system, the rio Uruguay basin, and along coastal drainages from São Paulo to Argentina, as well as in small drainage basins of western Argentina (Fig. 1).

The taxonomic history of the genus Cnesterodon began with Jenyns' (1842) description of Poecilia decemmaculata Jenyns, 1842, the first described species currently placed in the genus (Table 1). Later Günther (1866) removed $P$. decemmaculata from Poecilia Bloch \& Schneider, 1801 and placed it in the genus Girardinus Poey, 1854. Two years later, Hensel (1868) described two other species in Girardinus: $G$. januarius Hensel, 1868 and G. caudimaculatus Hensel, 1868 from Rio de Janeiro and Rio Grande do Sul, respectively. Subsequently, Boulenger (1889) described G. iheringii Boulenger, 1889. At that time, poeciliid species known from South America were solely assigned to genera Poecilia, Heterandria Agassiz, 1853 and Girardinus. "The Cyprinodonts" mono- graph of Garman (1895) represents the first attempt to extensively review the Cyprinodontiformes. Garman's classification was mainly based on tooth, jaw and anal-fin morphology. The genus Cnesterodon was erected by Garman (1895), with Poecilia decemmaculata as type-species, for it differed from the remaining genera so far assigned to Poeciliinae: Glaridodon Garman, 1895; Girardinus; Platypoecilus Günther, 1866; Mollienesia Lesueur, 1821; Poecilia, and Xiphophorus Heckel, 1848. Garman in the same paper also described a second species for the genus, C. scalpridens Garman, 1895. Glaridodon was erected by Garman (1895), in which he synonymized Girardinus caudimaculatus with $G$. januarius. Garman (1896) erected Glaridichthys as a replacement name for Glaridodon, preoccupied in Dinosauria by Glaridodon Seeley, 1888. Phillipi (1906, 1908) used the combination Glaridichthys decemmaculatus. A third nominal species, C. carnegiei Haseman was described from the rio Iguaçu drainage. Regan (1913) removed C. scalpridens from Cnesterodon and erected the genus Pamphoria Regan, 1913 [= Pamphorichthys Regan, 1913] for this species. Rosa \& Costa (1993) recognized the validity of $C$. decemmaculatus

Laboratório de Ictiologia Sistemática, Universidade Federal do Tocantins, Campus de Porto Nacional, rua 3, quadra 17, s/n, Jardim dos Ipês, Caixa Postal 136, 77500-000 Porto Nacional, TO, Brazil. e-mail: lucinda@uft.edu.br. 
Table 1. Taxonomic history of the genus Cnesterodon, Phalloptychus and Phalloceros until 1913.

\begin{tabular}{|c|c|c|c|c|}
\hline Author & Year & Nominal Taxa & Action & Valid Taxa \\
\hline Jenyns & 1842 & Poecilia decemmaculata & original description & Cnesterodon decemmaculatus \\
\hline Günther & 1866 & Girardinus decemmaculatus & new combination & Cnesterodon decemmaculatus \\
\hline Hensel & 1868 & Girardinus januarius & original description & Phalloptychus januarius \\
\hline Hensel & 1868 & Girardinus caudimaculatus & original description & Phalloceros caudimaculatus \\
\hline Boulenger & 1889 & Girardinus iheringii & original description & Phalloptychus iheringii \\
\hline \multirow[t]{4}{*}{ Garman } & \multirow[t]{4}{*}{1895} & Genus Cnesterodon & $\begin{array}{l}\text { genus erection } \\
\text { type species: Poecilia decemmaculata }\end{array}$ & Genus Cnesterodon \\
\hline & & Cnesterodon decemmaculatus & designation as type-species & Cnesterodon decemmaculatus \\
\hline & & Genus Glaridodon & $\begin{array}{l}\text { genus erection } \\
\text { type species: Girardinus uninotatus }\end{array}$ & Genus Girardinus \\
\hline & & Glaridodon caudimaculatus & new combination & Phalloceros caudimaculatus \\
\hline \multirow[t]{2}{*}{ Garman } & \multirow[t]{2}{*}{1896} & Genus Glaridichthys & replacement name & Genus Girardinus \\
\hline & & Glaridichthys caudimaculatus & new combination & Phalloceros caudimaculatus \\
\hline Phillipi & 1906 & Glaridichthys decemmaculatus & new combination & Cnesterodon decemmaculatus \\
\hline \multirow[t]{2}{*}{ Eigenmann } & \multirow[t]{2}{*}{1907} & Genus Phalloptychus & $\begin{array}{l}\text { genus erection } \\
\text { Type species: Girardinus januarius }\end{array}$ & Genus Phalloptychus \\
\hline & & Genus Phalloceros & $\begin{array}{l}\text { genus erection } \\
\text { type species: Girardinus caudimaculatus }\end{array}$ & Genus Phalloceros \\
\hline \multirow[t]{2}{*}{ Langer } & \multirow[t]{2}{*}{1913} & Genus Gulapinnus & $\begin{array}{l}\text { genus erection } \\
\text { type species: Poecilia decemmaculata }\end{array}$ & Genus Cnesterodon \\
\hline & & Gulapinnus decemmaculatus & new combination & Cnesterodon decemmaculatus \\
\hline
\end{tabular}

and C. carnegiei, and described C. brevirostratus Rosa \& Costa, 1993 from the upper rio Uruguay and rio Jacuí drainages, and C. septentrionalis Rosa \& Costa, 1993 from the rio Araguaia drainage. Latter, Lucinda \& Garavello (2000) described C. hypselurus Lucinda \& Garavello, 2001 from the rio Paranapanema basin, and C. omorgmatos Lucinda \& Garavello, 2001 a second species from the rio Iguaçu basin. Cnesterodon raddai Meyer \& Etzel, 2001 was described from the lower portions of rio Paraná. Recently, Lucinda (2003) reconized seven valid species in the genus: $C$. decemmaculatus, C. carnegiei, C. brevirostratus, $C$. septentrionalis, C. hypselurus, C. omorgmatos, and $C$. raddai.

\section{Materials and Methods}

The following counts were taken under a stereomicroscope: (a) predorsal scales: number of scales from posterior margin of large scale on dorsum of head to first dorsal-fin ray, excluding modified scale that may be present at origin of dorsal fin; (b) longitudinal series scales: counted from the second scale above pectoral fin insertion, to the end of hypural plate; (c) circumpeduncular scales; (d) scales in transverse row between origin of dorsal and anal fins, including minute scales present in some specimens at the base of anal fin; (e) number of epipleural ribs; (f) number of pleural ribs; (g) number of vertebrae: the urostyle is counted as one element; (h) number of fin rays: the last two rays in dorsal and anal fins were counted as independent elements. Gonopodial rays were counted in cleared and stained specimens. Rudimentary and procurrent rays were included in pectoral and caudal fin counts, respectively. All counts were made on the left side of adult specimens whenever possible. Adult males were considered those with a fully developed gonopodium. In species descriptions, numbers in square brackets following the counts indicate number of specimens for each count. Primary types counts are indicated by an asterisk. Morphometric data were obtained as distances between homologous landmarks on the lateral left surface of head and body. Specimens were digitalized as image files. Cartesian landmark coordinates were obtained using the software "TpsDig" version 1.37 by F. J. Rohlf (2003). Landmark distances were calculated using the software "LMDis" version 1.0 by R. E. Reis (1996). The table of descriptive morphometrics were elaborated with "Datax" version 4.2 by R. E. Reis and N. F. Fontoura (1993).

Thirteen landmarks were digitalized per specimen: (1) premaxillary tip, (2) supraoccipital tip, (3) origin of dorsal fin, (4) end of dorsal fin base, (5) base of middle caudal-fin rays, (6) point in dorsal profile of caudal peduncle, (7) point in ventral profile of caudal peduncle, (8) origin of anal fin, (9) end of anal-fin base, (10) base of first pelvic fin ray, (11) anterior margin of orbit, (12) posterior margin of orbit, (13) posterodorsal corner of opercle. Landmarks 6 and 7 were solely taken in order to measure caudal peduncle depth in the point of smallest depth. From these landmarks, the following measures were calculated: (a) standard length (SL), (b) head length (HL), (c) snout-occipital distance, (d) predorsal distance, (e) snout length, (f) orbital diameter, (g) dorsal-fin base length, (h) postorbital length, (i) anal-fin base length, (j) body depth, (l) pre-pelvic length, (m) pre-anal length, (n) post-anal length, (o) caudal peduncle depth. Measures, other than SL, are expressed as percents of SL, except those that are sub-units of the head, which are expressed as percents of HL. Clearing and staining followed the method of Taylor \& Van Dyke (1985). In species descriptions, numbers in square brackets following the counts indicate number of specimens for each count. The entries under examined material for each species follow the sequence: Country, "Estado", "Provincia" or "Departamento", institutional abbreviation, catalogue number, total number of examined specimens in the lot (number of cleared and stained specimens is indicated by an asterisk and separated from total number by a bar), type status, county, 


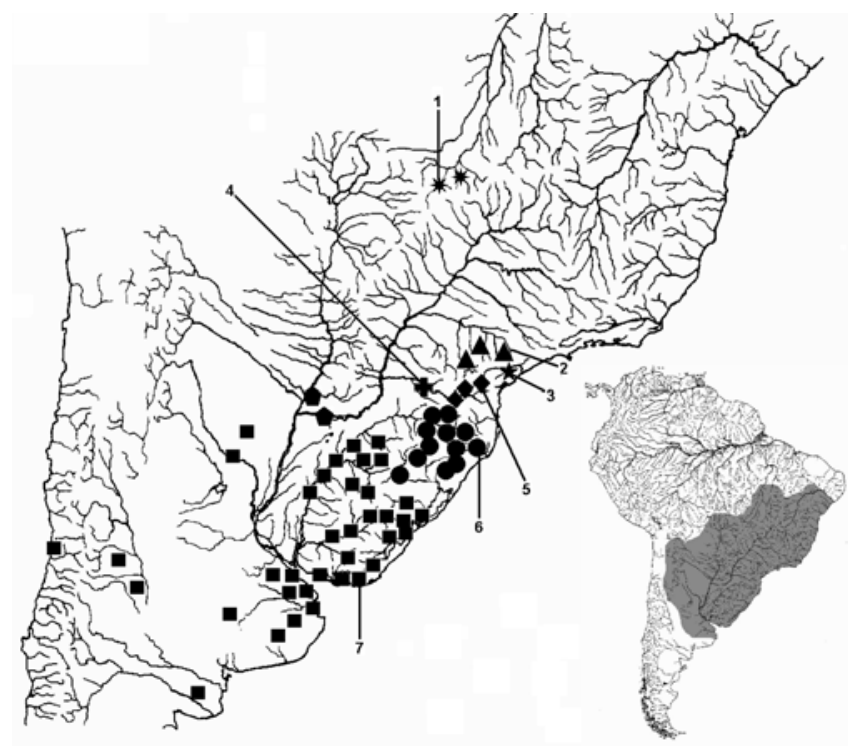

Fig. 1. Collection localities of Cnesterodon species: $C$. septentrionalis (eight-pointed stars, 1), C. hypselurus (triangles, 2), C. iguape (five-pointed stars, 3), C. omorgmatus (cross, 4), C. carnegiei (lozenges, 5), C. raddai (pentagons), C. brevirostratus (circles, 6), and C. decemmaculatus (squares, 7). Some symbols represent more than one lot or locality. Numbers represent type localities.

collection locality, date, collector(s). All geographic descriptors (including country) are in Portuguese or Spanish for Brazilian or Uruguayan and Argentinean localities, respectively. Type-localities are listed as in original descriptions. Description of all current valid species are not provided since they have been recently described or re-described in details.

Anatomical illustrations were prepared from sketches of structures from cleared and stained specimens as viewed through a camera lucida mounted on a dissecting stereomicroscope. Number and disposition of cephalic pores follow the nomenclature of Rosen \& Mendelson (1960), Gosline (1949) and Parenti (1981). Only adult individuals have been examined to avoid description of ontogenetic variation. Nomenclature of the gonopodium follows Rosen \& Gordon (1953). Descriptions of gonopodial morphology are based on fully developed gonopodia of large adult males. Osteological nomenclature adopted follows Rosen \& Bailey (1963) and Parenti (1981). Character state assignments, transformation series and clade numbers follow the phylogenetic analysis performed by Lucinda \& Reis (2005). All transformation series were considered unordered. Maximum parsimony analyses were undertaken using the $\mathrm{mh}^{*}$; bb* algorithm of Hennig86. Character optimization followed accelerated transformation model (ACCTRAN)

Institutional abbreviations follow Leviton et al. (1985), except for MNHCI: Museu de História Natural do Capão da Imbuia, Curitiba and MZUEL: Museu de Zoologia da Universidade Estadual de Londrina, Londrina.

\section{Results}

Synapomorphy List and Phylogenetic Reconstruction. Aphylogenetic hypothesis of relationships among Cnesterodon species is presented in the cladogram of Fig. 2. This hypothesis is part of a more inclusive phylogenetic study on the relationships among poeciliine genera, and the phylogenetic position of Cnesterodon in the subfamily Poeciliinae has already been discussed by Lucinda \& Reis (2005: fig. 1). Synapomorphies and autapomorphies are presented and discussed below. Uniquely derived and unreversed features are indicated by two asterisks (e.g. 37-2**).

\section{Genus Cnesterodon Garman, 1895 Clade [107]}

Cnesterodon Garman, 1895: 43. Gender masculine. Type-species: Poecilia decemmaculata Jenyns, 1842. Type by original designation.

Gulapinnus Langer, 1913: 207. Gender masculine. Type-species: Poecilia decemmaculata Jenyns, 1842. Type by original designation. Junior objective synonym of Cnesterodon Garman.

Diagnosis. Cnesterodon species share the following uniquely derived and unreversed features: (1) anterior tip of basipterygium sinuous in adult males [37-2**]; (2) outer surface of basipterygium base narrow in adult males [39-1**]; (3) haemal arch and spine of vertebrae 13-17 in adult males modified in rudimentary gonapophyses [47-3**]; (4) gonapophysis of vertebra 14 rudimentary in adult males [52$3^{* *}$;; (5) distal portion of plural ribs 6,7 , and 8 in adult males expanded [56-1**]; (6) large basal process on first anal-fin proximal radial in adult males [69-2**]; (7) unpaired appendix at tip of R3 [101-1**]; (8) distal segment at tip of R5a transformed in retrorse triangular spine [122-1**]; (9) dark spot posterior to anal-fin base of males continuous ventrally side by side and continuous with ventral median line of caudal peduncle [139-1**].

Additionally, the genus Cnesterodon is diagnosed by the following not uniquely derived and/or reversed features: (1) preopercular canal absent or opened in a shallow groove [81]; (2) posterior border of basipterygium anterior to posterior border of chleitrum [35-3]; (3) width of first pelvic-fin ray in adult males decreasing abruptly at distal portion, distal slender portion short [41-2]; (4) second pelvic-fin ray unbranched in adult males [42-1]; (5) ligastyle absent [46-0]; (6) absence of well-developed gonapophyses [48-0]; (7) functional gonapophyses absent [49-0]; (8) pleural rib 7 longer than pleural rib 8 in adult males [57-1]; (9) first proximal radial of dorsal fin in adult males located between neural spines of $12^{\text {th }}$ and $13^{\text {th }}$ vertebrae $[62-0] ;(10)$ gonactinost complex relative to body longitudinal axis very inclined backwards, forming a less than $45^{\circ}$ angle with body longitudinal axis [68-0]; (11) fusion of anal-fin posterior median radials ( $5^{\text {th }}$ to last) to re- 


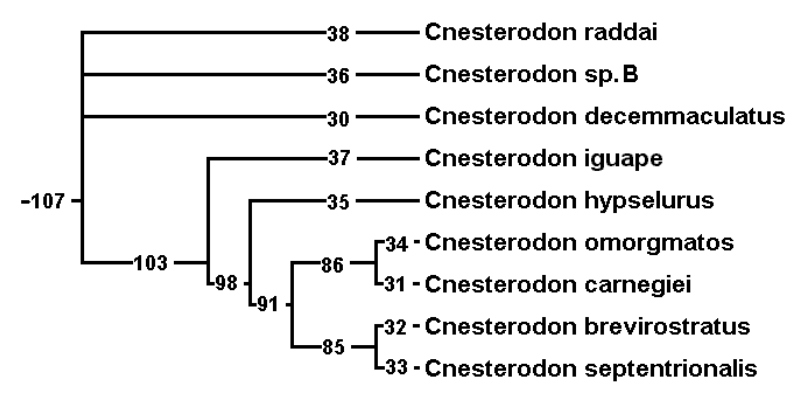

Fig. 2. Intrageneric relationships of Cnesterodon. The numbers on the branches refer to the character state transformations series by Lucinda \& Reis (2005).

spective proximal radials in adult males [77-1]; (12) lateral process on base of fifth median anal-fin radial very large in adult males [79-2]; (13) nine anal-fin rays in males [85-4]; (14) dorsal expansion present on R5p [124-1]; (15) more distal elements of branches of R6 totally fused [127-2]; (16) hypural plate completely fused [131-0]; and (17) absence of orbital bones [143-0].

Composition. Nine species: Cnesterodon decemmaculatus Jenyns, 1842; C. carnegiei, Haseman, 1911; C. brevirostratus Rosa \& Costa, 1993; C. septentrionalis Rosa \& Costa, 1993; C. omorgmatos Lucinda \& Garavello, 2001; C. hypselurus Lucinda \& Garavello, 2001; C. raddai Meyer \& Etzel, 2001; C. iguape sp. nov., and Cnesterodon sp.B, a new species being described by J. Anza, P. Lucinda, and L. Malabarba.

Distribution. Rio Uruguay drainage, laguna dos Patos system, río Negro, río Salado, western drainages of Argentina and small coastal drainages of Uruguay and Argentina, upper portions of the rio Iguaçu and its upper tributaries, the headwaters of the rio Maquiné in the Tramandaí system, and the headwaters of rio Itajaí-Açu drainage, upper rio Araguaia drainage, rio Paranapanema basin, rio Paraguay and lower rio Paraná drainages, upper rio Iporanga tributary of the rio Ribeira do Iguape (Fig. 1).

Remarks. Apparently Garman (1895) erected Cnesterodon based on immature male individuals judging from his figures. He stated: "As seen in Plate VIII., figs. 16 and 17, the modification of the anal fin of the male differs from that of both Glaridodon and Girardinus, in Plate VIII. Figs. 13 -15, and approaches that of Gambusia." Garman (1895) also synonymized Girardinus iheringii [= Phalloptychus iheringii] and Girardinus caudimaculatus [= Phalloceros caudimaculatus] with Girardinus januarius and placed the latter in his new genus Glaridodon. It is evident from Garman's figure of a male Glaridodon januarius (Plate VIII, fig. 15) showing a distal appendix on gonopodium, that he had only Phalloceros specimens at hand. Then, we conclude that Garman proposed Cnesterodon when comparing immature males with Phalloceros adult males. Further, Garman stated: "In the specimens dissected there were no subvertebral processes for

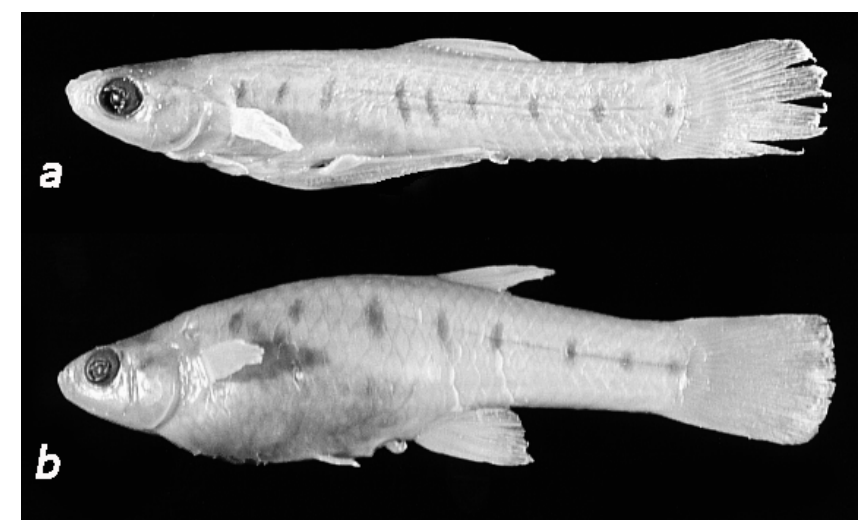

Fig. 3. Cnesterodon decemmaculatus. MLP 5623, General Fernando Oro, Río Negro, Argentina: (a) male, 20.6 mm SL; (b) female, $31.9 \mathrm{~mm}$ SL.

support of the anal fin" [= gonapophyses], Plate VIII, fig. 16, which left no doubt that he actually had Cnesterodon specimens at hand.

Phillipi (1906) placed $P$. decemmaculata in the genus Glaridichthys, a replacement name for Glaridodon (preoccupied in Dinosauria). Phillipi (1908) considered Girardinus caudimaculatus as a junior synonym of Glaridichthys januarius, but judging from his figures he had solely examined specimens of the first species. Langer (1913) has similarly confused the situation. Based on gonopodium differences, Langer created Gulapinnus for his Glaridichthys decemmaculatus. Therefore, Gulapinnus is a junior synonym of Cnesterodon.

\section{Cnesterodon decemmaculatus (Jenyns, 1842)}

(Fig. 3)

Poecilia decem-maculata Jenyns, 1842: 115, Plate 22. fig. 1, 1a. Type-locality: Maldonado [Uruguay]. BMNH 1917.7.14: 25, lectotype [by present designation]; BMNH 1917.7.14: 26, paralectotype. Maldonado. C. Darwin.

Poecilia gracilis Valenciennes in Cuvier \& Valenciennes, 1846: 133. Type-locality: environs de Montevidéo [Uruguay]. MNHN B-0939.

Diagnosis. Cnesterodon decemmaculatus is diagnosed by the following autapomorphies: (1) bony style at gonopodium tip of large adult males relatively long, slightly arched, and covered by a wide membrane progressively narrowing towards tip forming a distal filament (Rosa \& Costa, 1993; fig. 10); (2) membranous tip anterior to R4 and R5 absent [111-0]; and (3) membranous tip anterior to R4 and R5 absent [112-0].

Furthermore, C. decemmaculatus is readily distinguished from $C$. omorgmatos and $C$. raddai by dark brown blotches along body sides (forming bars $v s$. circular or irregular, respectively). Cnesterodon decemmaculatus is distinguished from C. carnegiei, C. hypselurus, and C. septentrionalis by dark bars on sides of body, mostly confined to midline, covering less than three scales in a transverse row, never extend- 


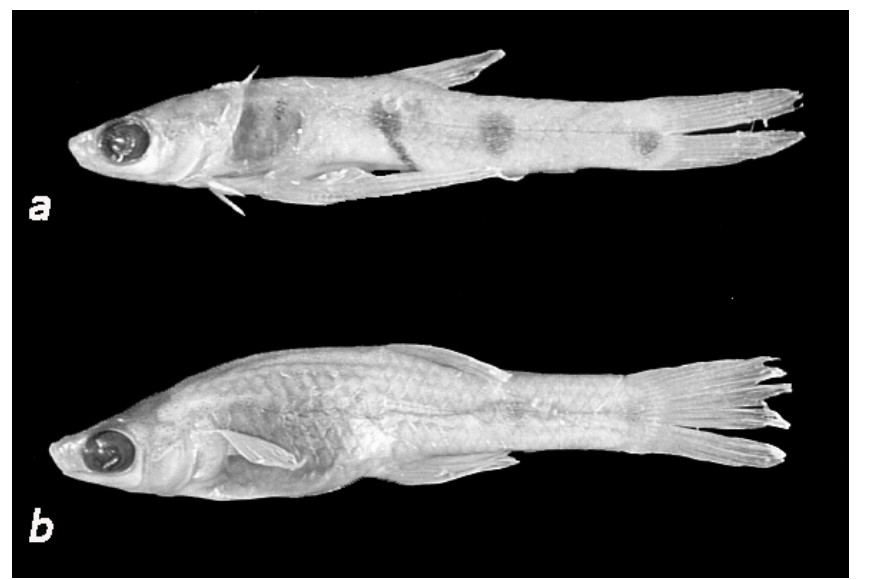

Fig. 4. Cnesterodon raddai. UMMZ 207503, small stream at bridge on dirt road to Ayolas, Misiones, Paraguay: (a) male, $16.9 \mathrm{~mm} \mathrm{SL}$; (b) female, $23.2 \mathrm{~mm}$ SL.

ing to dorsal and ventral profiles ( $v s$. dark bars of body very elongate reaching dorsal and ventral profiles, covering more than four scales in a transverse row). The absence of small scales covering lateral and ventral region of body below pectoral fin in adult females and the pointed snout distinguishes C. decemmaculatus from C. brevirostratus. Cnesterodon decemmaculatus is readily distinguished from $C$. iguape by the smaller post-gonopodium blotch on the ventral profile in adult males.

Distribution. Lower rio Uruguay, laguna dos Patos system, Río Negro, Río Salado, western drainages of Argentina and small coastal drainages of Uruguay and Argentina (Fig. 1).

Remarks. See Lucinda (2003) for discussion of type-locality.

\section{Cnesterodon raddai Meyer \& Etzel, 2001}

(Fig. 4)

Cnesterodon raddai Meyer \& Etzel, 2001: 248, fig. 1 (holotype, male); 2 (paratype, female); 3 (gonopodium) \& 4 (aquarium specimen, male). Type-locality: swamp near Resistencia, Rio Paraná basin, Argentina.

Diagnosis. Cnesterodon raddai is diagnosed by the following autapomorphies: (1) the small number (one to four) of patches of dark pigmentation along flanks; (2) minute size of adults; (3) predorsal line absent; (4) three pelvic-fin rays in males [33-3]. Cnesterodon raddai further differs from its congeners by: (1) pleural ribs in adult males not curved forward converging to the same point towards pelvic girdle [59-0]; and (2) anterior and posterior orbital bony plates present [143$1]$.

In addition, $C$. raddai differs from its congeners, but $C$. omorgmatos, by the circular or irregular dark brown blotches along body sides. Cnesterodon raddai is distinguished from C. omorgmatos by the general size of adults (14.6-17.0 mm [adult males], 17.1-23.2 mm [adult females] vs. 18.7-24.8 mm

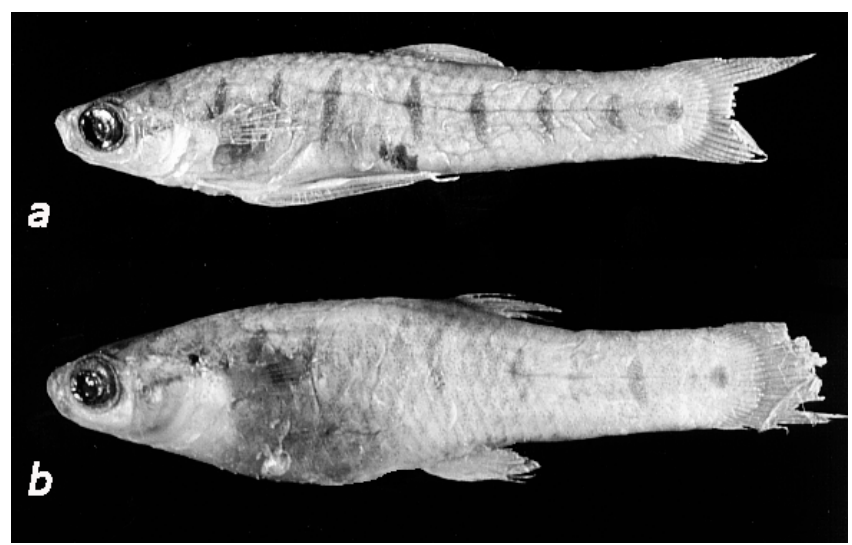

Fig. 5. Cnesterodon iguape: (a) holotype, male, MZUSP 79672, Apiaí, São Paulo, Brazil, 22.3 mm SL; (b) paratype, female, MZUSP 54978, $24.8 \mathrm{~mm}$ SL, collected with the holotype.

[adult males], 20.0-30.5 mm [adult females], respectively) and by its color pattern (one to four clearly rounded dark spots or wide and short bars along flanks vs. six to nine dark brown circular to irregular blotches or vertical wide bars along body sides, respectively).

Distribution. Cnesterodon raddai is distributed in the rio Paraguay and lower rio Paraná drainages.

\section{Cnesterodon iguape $+C$. hypselurus $+C$. septentrionalis + C. brevirostratus $+C$. carnegiei $+C$. omorgmatos Clade [103]}

Diagnosis. Members of this clade share the following uniquely derived and unreversed feature: constriction of unpaired appendix of gonopodium [103-1**].

Additionally, this clade is diagnosed by the following not uniquely derived and/or reversed features: (1) medial surface of ascending process of premaxilla approximately straight [110]; (2) teeth on fourth ceratobranchial [27-0]; (3) first proximal radial of dorsal fin located between neural spines of $13^{\text {th }}$ and $14^{\text {th }}$ vertebrae in adult males [62-1].

\section{Cnesterodon iguape, new species}

(Fig. 5 and 6, Table 2)

Holotype. MZUSP 79672, male, Brazil. São Paulo. Apiaí, creek on headwaters of rio Iporanga, inside Mineradora Oxical, 2424'42"S 48³9'25", W. Buck et al., 4 Apr 1999. Paratypes. MZUSP 54978, 12 / 2*, collected with the holotype.

Diagnosis. Cnesterodon iguape is diagnosed by the following autapomorphy: a large post-gonopodium blotch on the ventral profile in adult males.

Furthermore, C. iguape is distinguished from its congeners by distal portion of anal-fin proximal radials 2 and 3 in adult males fused [72-1]. Cnesterodon iguape is readily distinguished from $C$. omorgmatos and $C$. raddai by dark brown blotches along body sides (forming bars vs. circular or irregu- 


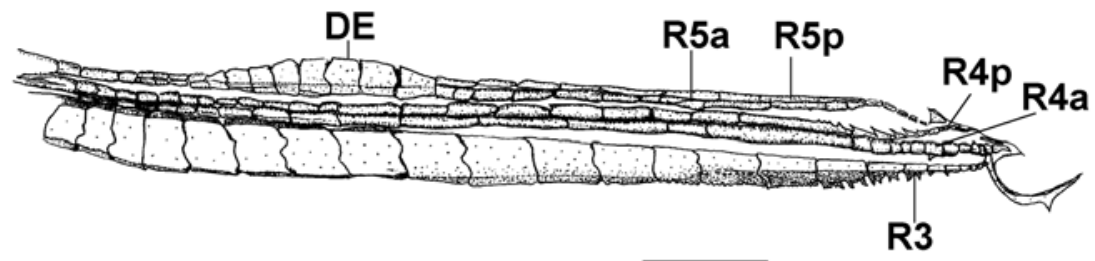

Fig. 6. Gonopodium tip of Cnesterodon iguape, MZUSP 54978. Bar $1 \mathrm{~mm}$. DE = dorsal expansion. R3, R4a, R4p, R5a, R5p= gonopodial rays.

lar, respectively). It is distinguished from C. brevirostratus by the pointed snout and by the absence of minute scales covering lateral and ventral regions of body below pectoral fin in adult females. The absence of a very prominent dark brown longitudinal band along body sides (longitudinal band along body lacking or faint) distinguishes it from $\mathrm{C}$. hypselurus. Cnesterodon iguape is distinguished from $C$. carnegiei, C. septentrionalis, and C. hypselurus by the presence of dark bars on sides of body vertically short, mostly confined to midline, covering less than three scales in a transverse row, never extending to dorsal and ventral profiles. Cnesterodon iguape is distinguished from $C$. decemmaculatus by the configuration of the bony style at gonopodium tip in adult males (relatively long and slightly arched, and bearing a membrane progressively narrowing towards tip forming a distal filament $v s$. relatively short and very arched. Membrane on bony style never forming a distal filament in C. decemmaculatus) (Fig. 6).

Description. Morphometric data in Table 2. Range of SL: 18.5 to $24.9 \mathrm{~mm}$ (females); 18.5 to $22.4 \mathrm{~mm}$ (males). Body compressed, width in predorsal region uniform, about half body depth. Post-dorsal region compressed towards caudal peduncle. Predorsal profile convex. Dorsal-fin base convex. Postdorsal profile slightly concave. Pre-anal profile very convex. Anal-fin base oblique. Post-anal profile concave in females, and almost straight in males. Dorsal fin with semicircular border, located posteriorly to mid-body. Origin of dorsal fin in females on vertical passing through base of third analfin ray; in males, origin of dorsal fin posterior to vertical passing through origin of anal fin. Pectoral fin with high insertion in horizontal passing through orbital center. Longest ray reaching about seventh scale in longitudinal series. Pelvic fin small, pointed and not reaching origin of gonopodium in adult males; not reaching origin of anal fin in females. Anal fin of females with straight border. Origin of anal fin of females closer to caudal peduncle than to snout tip. Origin of anal fin of males closer to snout tip than to caudal peduncle. Mouth superior, almost aligned with upper border of pupil.

Dorsal-fin rays: 7 [1], 8* [9], 9 [1]. Pectoral-fin rays: 10* [2], 11 [7], 12 [2]. Pelvic-fin rays: 4* (males), 5 (females). Analfin rays (females): 10 [4]; Gonopodial rays: 8 [5]. Caudal-fin rays: 26 [1], 27 [5], 28* [6]. Pre-dorsal scales: 12 [4], 13* [2], 14 [3]. Longitudinal series scales: 27 [1], 28 [6], 29* [2], 30 [1], 33 [1]. Scales around caudal peduncle: $16^{*}[13]$. Scales in transverse row: 10 [9], 11 [2], 12* [2]. Pleural ribs: 15 [2]. Epipleural ribs: 8 [2]. Vertebrae: 32 [1], 33 [1].

Gonopodial complex composed of 10 gonactinosts. Functional gonapophyses absent. Gonactinosts 2, 3, 4 fused. Gonactinost 4 with wing-like expansions. Ligastyle absent. Gonopodium symmetrical. Eight gonopodial rays. Rays 1 and 2 unbranched and short. Ray 1 with 5-7 segments. Ray 2 with 7 or 8 segments. Ray 3 with 23 or 24 segments. At tip, long slender bony style bearing narrow membrane produced in terminal filament. Four or five paired retrorse spines on distal segments of ray $4 \mathrm{p}$. Ray $5 \mathrm{a}$ with subdistal and discrete dorsal curvature and terminated by retrorse claw. Dorsal convexity located between segments 11 to 19 of ray $5 \mathrm{p}$. Rays 6, 7 and 8 branched. Distal segments of rays 6 and 7 partially ankylosed.

Color in alcohol. Eye black with greenish brown pupil. Background color cream yellow. Scale borders and subjacent skin replete with brown chromatophores, conferring reticulate pattern to body sides. Dorsum darker than ventral region. Head dorsum dark brown. Median dark brown line along predorsal surface. Median dark brown line along preanal surface (inconspicuous in large females). Fins hyaline. Fin rays with two rows of brown chromatophores on each side, along entire ray. Seven to nine dark brown vertical bars along body sides, mostly confined to midline. Large blotch on each side of ventral portion of body near gonopodium, meeting midventral post-anal line.

Distribution. Known only from the type-locality in the upper rio Iporanga (Fig. 1).

Etymology. Cnesterodon iguape is named after the rio Ribeira de Iguape, in whose headwaters is the type-locality.

\section{C. hypselurus + C. septentrionalis $+C$. brevirostratus \\ + C. carnegiei + C. omorgmatos Clade [98]}

Diagnosis. Members of this clade share the following not uniquely derived and/or reversed features: (1) first proximal radial of dorsal fin located between neural arches of $12^{\text {th }}$ and $13^{\text {th }}$ vertebrae in adult females [63-0]; and (2) distal portion of third and fourth anal-fin proximal radials in adult males separate, except by tip of gonactinost [74-2]. 


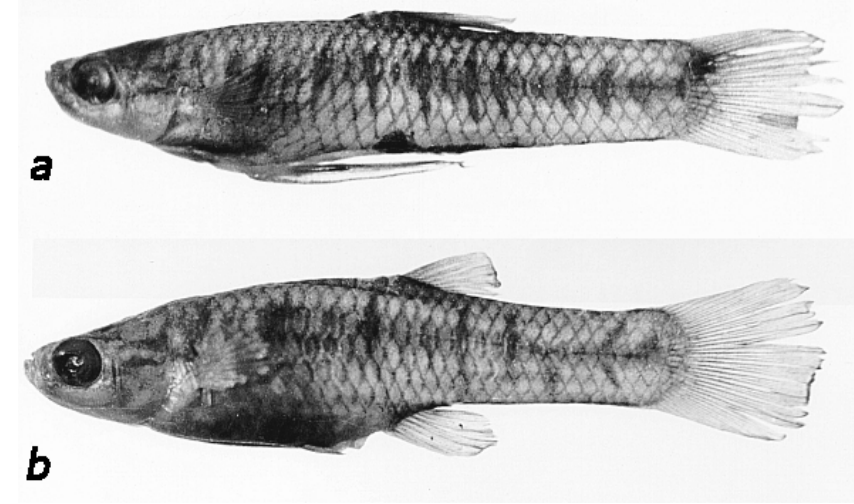

Fig. 7. Cnesterodon hypselurus: (a) holotype, male, MCP 22743, rio Cilada, Jaguariaíva, Paraná, Brazil. 23.9 mm SL; (b) paratype, female, MCP 22744, $28.0 \mathrm{~mm} \mathrm{SL}$, collected with the holotype.

\section{Cnesterodon hypselurus Lucinda \& Garavello, 2001 (Fig. 7)}

Cnesterodon hypselurus Lucinda \& Garavello, 2001: 29, fig. 5 and 6. Type-locality: Brasil. Paraná. rio Cilada, bridge of road BR 151, rio Paranapanema drainage, Jaguariaíva.

Diagnosis. Cnesterodon hypselurus is diagnosed by the following autapomorphies: (1) presence of a longitudinal dark brown band along flank. (2) bony style of ray 3 of gonopodium of fully developed mature males curly-bracket shaped (Lucinda \& Garavello, 2001; fig. 6).

Furthermore, C. hypselurus is readily distinguished from C. omorgmatos and $C$. raddai by dark brown blotches along body sides (forming bars vs. circular or irregular, respectively). Cnesterodon hypselurus is distinguished from $C$. decemmaculatus, C. brevirostratus, and $C$. iguape by dark bars of body very elongate reaching dorsal and ventral profiles, covering more than four scales in a transverse row ( $v s$. dark bars on sides of body, mostly confined to midline, covering less than three scales in a transverse row, never extending to dorsal and ventral profiles). The absence of small scales covering lateral and ventral region of body below pectoral fin and the pointed snout also differentiate $C$. hypselurus from C. brevirostratus. Cnesterodon hypselurus is distinguished from $C$. septentrionalis, $C$. omorgmatos, and $C$. decemmaculatus, by the number of epipleural ribs (10-12 vs. 6 in C. septentrionalis, 7 or 8 in $C$. omorgmatos and $C$. decemmaculatus).

Distribution. Cnesterodon hypselurus is known from rio Cilada, rio Lambari and rio Guaricanga in upper rio Paranapanema basin, rio Paraná drainage (Fig. 1).

$$
\begin{gathered}
\text { C. septentrionalis }+ \text { C. brevirostratus }+C . \text { carnegiei } \\
+ \text { C. omorgmatos } \\
\text { Clade }[91]
\end{gathered}
$$

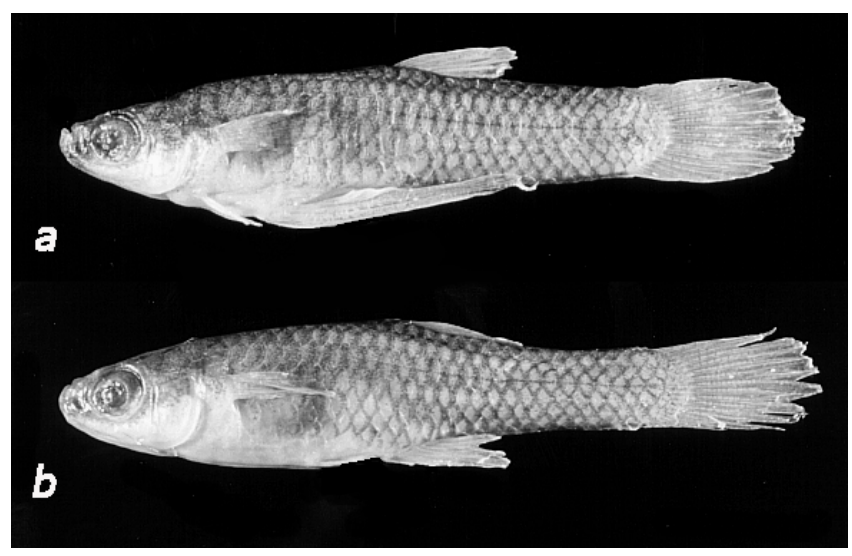

Fig. 8. Cnesterodon septentrionalis. MZUSP 69685, córrego do Mosquito, upper rio Araguaia, Mato Grosso: (a) male, 16.8 mm SL; (b) female, $19.3 \mathrm{~mm}$ SL.

Diagnosis. Members of this clade share the following not uniquely derived and/or reversed feature: four pelvic-fin rays in males [33-2].

\section{C. septentrionalis + C. brevirostratus Clade [85]}

Diagnosis. Members of this clade share the following not uniquely derived feature: teeth conical [21-0].

\section{Cnesterodon septentrionalis Rosa \& Costa, 1993} (Fig. 8)

Cnesterodon septentrionalis Rosa \& Costa, 1993: 706, figs. 13, 18. Type-locality: Brazil, Mato Grosso, Município de Alto Araguaia, swamp near the Córrego do Rancho fountainhead.

Diagnosis. Cnesterodon septentrionalis is diagnosed by the following autapomorphies: (1) six epipleural ribs; and (2) bony style of ray 3 of gonopodium of fully developed mature males large and very curved upwards, almost describing a semicircular outline, and invested with few membranous tissue (Rosa \& Costa, 1993; fig. 13). Cnesterodon septentrionalis is readily distinguished from its congeners by the branched second pelvic-fin ray in adult males [42-0]; pleural ribs not associated with haemal arches in males [60-0]; first proximal radial of dorsal fin located between neural spines of $11^{\text {th }}$ and $12^{\text {th }}$ vertebrae in adult males [62-6]; first proximal radial of dorsal fin in adult females located between neural arches of vertebrae $11^{\text {th }}$ and $12^{\text {th }}[63-3]$; less than nine caudal-fin rays entirely lying over on hypural plate [132-0].

Furthermore, Cnesterodon septentrionalis is distinguished from $C$. omorgmatos and $C$. raddai by dark brown blotches along body sides (forming bars vs. circular or irregular, respectively). Cnesterodon septentrionalis is distinguished from $C$. decemmaculatus, $C$. brevirostratus, and $C$. iguape by dark bars of body very elongate reaching dorsal 


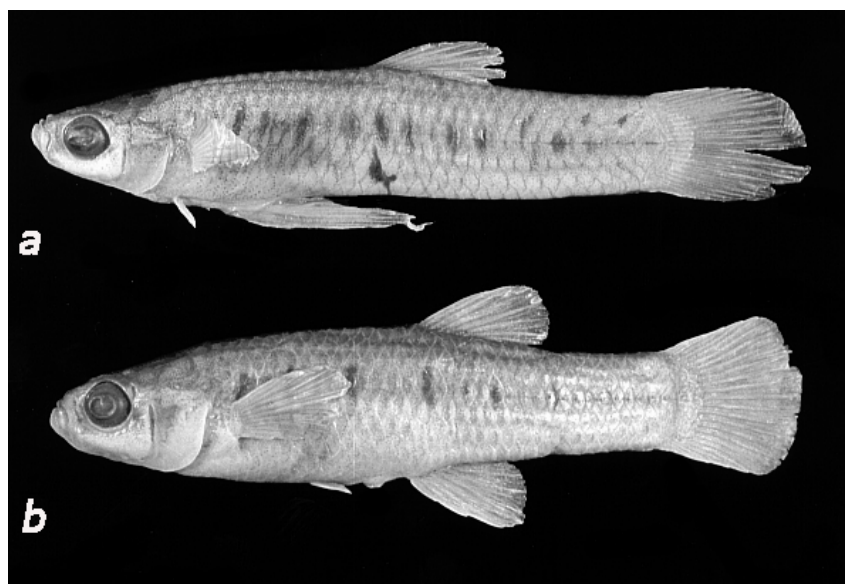

Fig. 9. Cnesterodon brevirostratus. MCP 26050, São José dos Ausentes, Rio Grande do Sul, Brazil: (a) male, 25.2 mm SL; (b) female, $33.7 \mathrm{~mm}$ SL.

and ventral profiles, covering more than four scales in a transverse row ( $v s$. dark bars on sides of body, mostly confined to midline, covering less than three scales in a transverse row, never extending to dorsal and ventral profiles). The absence of small scales covering lateral and ventral region below pectoral fin and the pointed snout also differentiates $C$. septentrionalis from $C$. brevirostratus. The absence of a longitudinal dark brown band along flank differentiates $C$. septentrionalis from $C$. hypselurus. Cnesterodon septentrionalis differs from $C$. carnegiei by the number of caudal fin rays (20-22 vs. 25-26, respectively), by the number of longitudinal series scales (25-26 vs. 28-31, respectively) and by the number of transverse rows between dorsal and anal fin (7vs. 8-10, respectively).

Distribution. Upper rio Araguaia drainage (Fig. 1).

\section{Cnesterodon brevirostratus Rosa \& Costa, 1993 (Fig. 9)}

Cnesterodon brevirostratus Rosa \& Costa, 1993: 705, fig. 17. Type-locality: Brazil, Rio Grande do Sul, Cambará do Sul, Parque Nacional dos Aparados da Serra, Arroio Camisa, tributary to Rio das Antas.

Diagnosis. Cnesterodon brevirostratus is diagnosed by the following autapomorphies: (1) snout blunt; (2) presence of small scales covering lateral and ventral region of body below pectoral fin in adult females; (3) bony style of ray 3 of gonopodium of fully developed mature males large and sinuous, covered with few membranous tissue (Rosa \& Costa, 1993; fig. 11). Furthermore, C. brevirostratus is readily distinguished from $C$. omorgmatos and $C$. raddai by dark brown blotches along body sides (forming bars vs. circular or irregular, respectively). Cnesterodon brevirostratus is distinguished from C. carnegiei, C. hypselurus, and C. septentrionalis by dark bars on sides of body, mostly confined to midline, covering less than three scales in a transverse row, never extend-

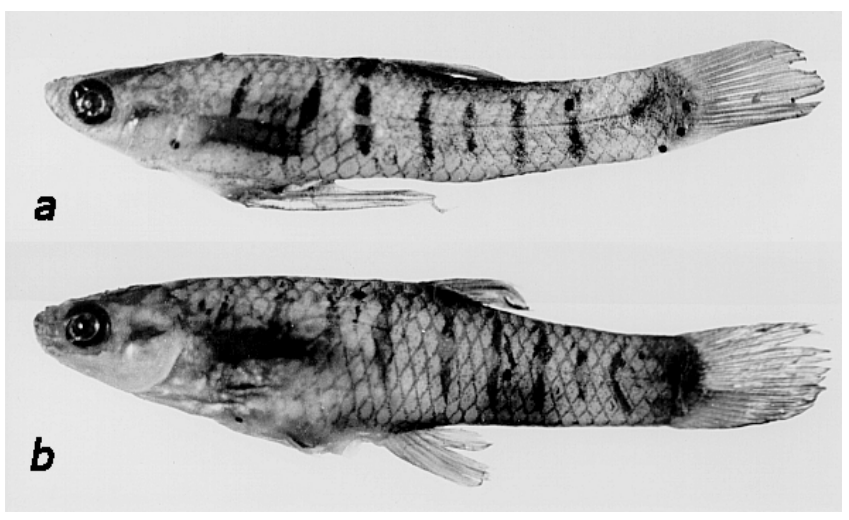

Fig. 10. Cnesterodon carnegiei. MHNCI 7609, rio Passaúna, Almirante Tamandaré, Paraná, Brazil: (a) male, 24.3 mm SL; (b) female, $30.1 \mathrm{~mm}$ SL.

ing to dorsal and ventral profiles (vs. dark bars of body very elongate reaching dorsal and ventral profiles, covering more than four scales in a transverse row). The absence of a longitudinal dark brown band along flank differentiates $C$. brevirostratus from C. hypselurus.

Distribution. Cnesterodon brevirostratus inhabits the upper portion of the rio Pelotas and rio Canoas of the rio Uruguay drainage, the rio Jacuí, the headwaters of the rio Maquiné in the Tramandaí system, and the headwaters of rio ItajaíAçu drainage.

Remarks. The color pattern of C. brevirostratus is quite variable. It can be a typical Cnesterodon pattern with vertical bars along flanks, a pattern of bars irregularly set and shaped, or even dotted.

\section{C. carnegiei + C. omorgmatos Clade [86]}

Diagnosis. Members of this clade share the following not uniquely derived and/or reversed feature: medial surface of ascending process of premaxilla angled laterally at proximal end, forming a triangular space between proximal ends of ascending processes [11-2].

\section{Cnesterodon carnegiei Haseman, 1911}

(Fig. 10)

Cnesterodon carnegiei Haseman, 1911: 385. Plate 83. Typelocality: Serrinha, Paraná.

Diagnosis. Cnesterodon carnegiei is readily distinguished from $C$. omorgmatos and $C$. raddai by dark brown blotches along body sides (forming bars $v s$. circular or irregular, respectively). Cnesterodon carnegiei is distinguished from $C$. decemmaculatus, C. brevirostratus, and C. iguape by dark bars of body very elongate reaching dorsal and ventral profiles, covering more than four scales in a transverse row ( $v s$. 


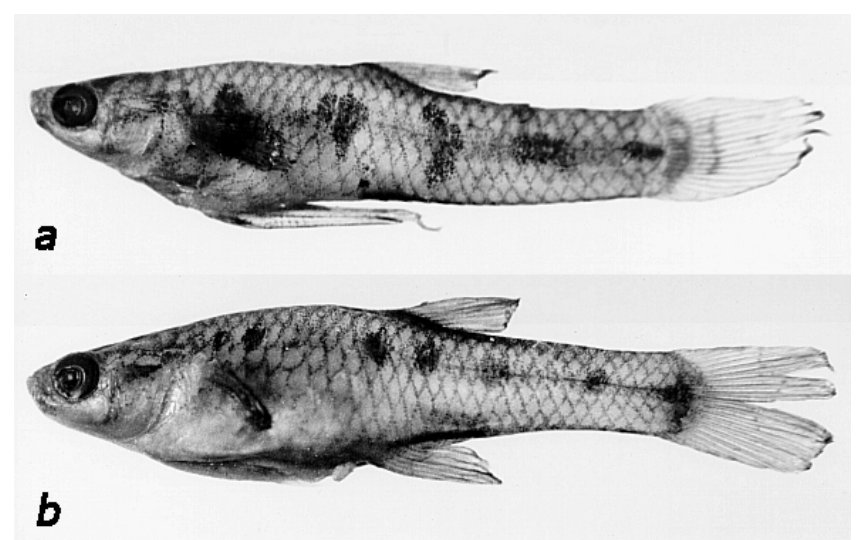

Fig. 11. Cnesterodon omorgmatos: (a) holotype, male, MCP 22741, rio das Torres, Pinhão, Paraná, Brazil. 24.3 mm SL; (b) paratype, female, MCP 22742, $27.9 \mathrm{~mm} \mathrm{SL}$, collected with the holotype.

dark bars on sides of body, mostly confined to midline, covering less than three scales in a transverse row, never extending to dorsal and ventral profiles). The absence of small scales covering lateral and ventral region below pectoral fin and the pointed snout also differs $C$. carnegiei from C. brevirostratus. The absence of a longitudinal dark brown band along flank differentiates $C$. carnegiei from $C$. hypselurus. Cnesterodon carnegiei is distinguished from $C$. septentrionalis, $C$. omorgmatos, and $C$. decemmaculatus, by the number of epipleural ribs (10-12 vs. 6 in C. septentrionalis, 7 or 8 in $C$. omorgmatos and $C$. decemmaculatus). Cnesterodon carnegiei also differs from $C$. septentrionalis by the number of caudal-fin rays (25-26 vs. 20-22, respectively), by the number of longitudinal scales (28-31 vs. 25-26, respectively) and by the number of transverse rows between dorsal and anal fin (8-10vs. 7, respectively).

Distribution. Cnesterodon carnegiei is known from the upper portions of rio Iguaçu and its upper tributaries (Fig. 1).

\section{Cnesterodon omorgmatos Lucinda \& Garavello, 2001} (Fig. 11)

Cnesterodon omorgmatos Lucinda \& Garavello, 2001: 126. fig. 3 and 4. Type-locality: Brasil, Paraná, rio das Torres, rio Iguaçu basin, Pinhão.

Diagnosis. Cnesterodon omorgmatos is distinguished from its congeners, except $C$. decemmaculatus, by the number of epipleural ribs ( 7 or 8 vs. 6 in C. septentrionalis and 10-12 in remaining species). Cnesterodon omorgmatos differs from its congeners, but $C$. raddai by the presence of circular or irregular dark brown blotches along body sides. Cnesterodon omorgmatos is distinguished from $C$. raddai by the general size of adults (18.7-24.8 $\mathrm{mm}$ [adult males], 20.0-30.5 $\mathrm{mm}$ [adult females] vs. 14.6-17.0 mm [adult males], 17.1-23.2 mm [adult females], respectively) and by its color pattern (six to nine dark brown circular to irregular blotches or vertical wide bars along body sides vs. two to four clearly rounded dark spots along body sides, respectively).

Distribution. Cnesterodon omorgmatos is known solely from the type-locality in the rio Iguaçu basin (Fig. 1).

\section{Key to species of Cnesterodon}

1. Minute scales covering lateral and ventral regions of body below pectoral fin, mainly in females (upper portion of the rio Pelotas and rio Canoas of the rio Uruguay drainage, rio Jacuí as well as the headwaters of the rio Maquiné in the Tramandaí system and the headwaters of rio ItajaíAçu drainage) C. brevirostratus

1'. Scales covering lateral and ventral regions of body below pectoral fin approximately of the same size of adjacent scales.

2. Caudal peduncle in adult males deep (15.5-17.8 \% SL); a prominent dark brown longitudinal band along body sides (rio Cilada, rio Lambari, and rio Guaricanga in upper rio Paranapanema basin, rio Paraná drainage) .... C. hypselurus

2'. Caudal peduncle in adult males low (10.7-15.1\% SL); longitudinal band along body sides lacking or faint ................ 3

3. Dark brown blotches along body sides circular or irregular ......4

3'. Dark brown blotches along body sides vertical forming bars ....5

4. Six to nine dark brown circular to irregular blotches along body sides; normal size (18.7-24.8 mm [adult males], 20.0$30.5 \mathrm{~mm}$ [adult females]) (rio das Torres, rio Iguaçu basin) C. omorgmatos

4'. Two to four dark brown circular blotches along body sides; minute size (14.6-17.0 mm [adult males], 17.1-23.2 mm [adult females]) (rio Paraguai and lower rio Paraná drainages)

C. raddai

5. Dark bars on sides of body vertically short, mostly confined to midline, covering less than three scales in a transverse row, never extending to dorsal and ventral profile ............6

5 '. Dark bars on sides of body vertically elongate, covering more than four scales in a transverse row, occasionally reaching dorsal and ventral profiles

7

6. Post-gonopodium blotch on ventral profile normally developed; bony style at gonopodium tip in adult males comparatively long and slightly arched; membrane on bony style large and progressively narrowing towards tip forming a distal filament (lower rio Uruguay, laguna dos Patos system, río Negro, río Salado, western drainages of Argentina and small coastal drainages of Uruguay and Argentina) .................................... C. decemmaculatus

6' Post-gonopodium blotch on ventral profile large; bony style at gonopodium tip in adult males comparatively short and very arched; membrane on bony style never forming a distal filament (rio Ribeira de Iguape drainage) .... C. iguape

7. Twenty-five or 26 caudal-fin rays; 28 to 31 scales on longitudinal series (upper portions of rio Iguaçu and its upper tributaries) C. carnegiei

7 ' Twenty to 22 caudal-fin rays; 25 or 26 scales on longitudinal series (upper rio Araguaia drainage) ............ . septentrionalis 
Table 2. Descriptive morphometrics of specimens of Cnesterodon iguape, new species. Measurements 1-10 are percents of standard length and measurements 11-13 are percents of head length.

\begin{tabular}{lccccc}
\hline & & Males $(\mathrm{n}=6)$ & \multicolumn{2}{c}{ Females $(\mathrm{n}=4)$} \\
\hline Character & Holotype & Range & Mean & Range & Mean \\
\hline Standard length $(\mathrm{mm})$ & 22.4 & $18.5-22.4$ & 19.7 & $18.5-24.9$ & 21.4 \\
1. Head length & 18.1 & $18.1-21.3$ & 20.3 & $21.8-26.6$ & 23.7 \\
2. Snout-occipital & 19.4 & $19.4-22.0$ & 20.7 & $21.1-24.9$ & 22.6 \\
3. Predorsal distance & 53.5 & $52.8-56.3$ & 54.1 & $57.7-59.9$ & 58.8 \\
4. Dorsal-fin base length & 9.0 & $7.6-9.0$ & 8.4 & $5.7-8.9$ & 7.6 \\
5. Anal-fin base length & 6.8 & $6.8-9.6$ & 7.8 & $6.6-8.3$ & 7.2 \\
6. Body depth & 32.2 & $30.0-34.4$ & 32.0 & $23.2-25.2$ & 24.0 \\
7. Pre-pelvic length & 22.7 & $22.7-25.9$ & 24.4 & $40.9-44.1$ & 42.0 \\
8. Preanal length & 31.4 & $31.3-34.9$ & 32.9 & $53.8-56.8$ & 54.9 \\
9. Postanal length & 65.4 & $60.7-66.2$ & 63.9 & $38.6-42.6$ & 41.3 \\
10. Caudal peduncle depth & 13.6 & $12.1-13.6$ & 13.0 & $12.1-14.5$ & 13.2 \\
11. Snout length & 19.8 & $17.1-21.1$ & 19.4 & $16.9-21.9$ & 20.0 \\
12. Orbital diameter & 43.8 & $35.5-43.8$ & 38.0 & $49.4-57.2$ & 53.5 \\
13. Postorbital length & 38.6 & $38.6-45.8$ & 43.7 & $43.5-51.1$ & 47.3 \\
\hline
\end{tabular}

Material examined: Cnesterodon brevirostratus. Brazil. Santa Catarina: MCP 14375, 558/2*, Lages, Painel, creek tributary of rio Caveiras on road from São Joaquim to Lages, 16 Jan 1989. MCP 16569, 4, Taió, creek on road Taió-Passo Manso, on bridge, 15 Oct 1993. USNM 320236, 60, creek tributary of rio Caveiras at Painel on road from São Joaquim to Lages, 15 Nov 1991. Rio Grande do Sul: MCP 8628, 26, paratypes, Bom Jesus, rio Tourinhos, 30 Sep 1980. MCP 8630, 21, headwaters of rio dos Touros; 23 Sep 1980. MCP 8631, 65, paratypes, São Francisco de Paula, headwaters of rio Santa Cruz, 27 Sep 1980. MCP 8632, 13, Cambará do Sul, rio Camisas, 30 Sep 1980. MCP 8633, 17, Bom Jesus, rio Manuel Leão, 31 Sep 1980. MCP 8635, 8, Vacaria, Passo do Carro, 25 Sep 1980. MCP 8636, 9, Bom Jesus, rio Divisa, 24 Sep 1980. MCP 8637,8 , Bom Jesus, headwaters of rio Marco, 24 Sep 1980. MCP 8638, 4, Bom Jesus, rio Lageadinho, 23 Sep 1980. MCP 8641, 10; MCP 13951, 42, Cambará do Sul, arroio Areia, 31 Sep 1980. MCP 10629, 52, Vacaria, headwaters of arroio Lageado Bonito, road Vacaria Bom Jesus, 4 May 1985. MCP 10651, 10, São Francisco de Paula, paratypes, rio Tainhas, 1 May 1985. MCP 10653, 59, Cambará do Sul paratypes, arroio Camisa, tributary of rio das Antas, Parque Nacional dos Aparados da Serra, 1 May 1985. MCP 10657, 25, paratypes, arroio Cachoeirinha, road Vacaria Bom Jesus, 4 May 1985. MCP 11144, 16, São Francisco de Paula, creek on road São Francisco de Paula, tributary of rio Santa Cruz, 16 May 1987. MCP 11146, 9; MCP 13952, 24, São Francisco de Paula, arroio Dizineiro on road from São Francisco de Paula to Lageado Grande, 15 May 1987. MCP 11147, 16, São Francisco de Paula, small creek tributary of arroio Buriti in Lageado Grande, 16 May 1987. MCP 13941, 8, Cambará do Sul, arroio Camisa, on road in Parque Nacional dos Aparados da Serra, 1 May 1985. MCP 13942, 4, São Francisco de Paula, rio Tainhas, 1 May 1985. MCP 13950, 27/4*, Bom Jesus, rio Manuel Leão, 31 Sep 1980. MCP 14350, 4, Bom Jesus, tributary of rio dos Touros on road Silveira Rondinha, 14 Jan 1989. MCP 16447, 3, Erechim, rio Tigre, 22 Nov 1985. MCP 16563, 23, Caxias do Sul, fazenda Sousa, 15 Nov 1993. MCP 19828, 5, São Francisco de Paula, rio Contendas on road Aratinga Tainhas, 4 Jun 1997. MCP 19785, 324/6*, São Francisco de Paula, arroio da Serraria in road from Potreiro Velho to Pró-Mata, 3 May 1997. MCP 19789, 1; MCP 19790, 1, São Francisco de Paula, Potreiro Velho, PróMata, 1 May 1997. MCP 22312, 8, São José dos Ausentes, arroio da Sepultura in road from Silveira to Bom Jardim da Serra, 17 Dec 1998. MCP 22314, 215, São José dos Ausentes, creek tributary to rio Manuel Leão between Silveira and São José dos Ausentes, 17 Dec 1998. MCP 22315, 21; MCP 22319, 5, Tainhas, arroio Ribeirão ca $7.3 \mathrm{~km}$ NW from trevo de Tainhas by "Rota do Sol", 16 Dec 1998. MCP 22316, 1, São José dos Ausentes, rio Silveira, 17 Dec 1998. MCP 22317, 15; MCP 22320, 14, Tainhas, creek tributary of rio Tainhas $c a 1.7 \mathrm{~km} \mathrm{NW}$ from Trevo de Tainhas by "Rota do Sol", 16 Dec 1998. MCP 22318, 22, Lageado Grande, headwaters of rio Lageado Grande, $c a 1 \mathrm{~km}$ south of Várzea do Cedro by road RS 110 , 16 Dec 1998. MCP 23874, 8, Glorinha, arroio Itajaçu, 18 Apr 1999. MCP 25352, 20, Tainhas, headwater of rio Maquiné, northerly from fazenda Lageado in Potreiro Velho, 2 May 1999. MCP 25386, 32, same data as for MCP 25352. MCP 25651, 6, São José dos Ausentes, rio das Antas a upstream camping Vale das Trutas $c a 10$ km E of São José dos Ausentes, 24 Mar 2000. MCP 25653, 48, São Francisco de Paula, rio Contendas on road from Aratinga to Tainhas, 20 Mar 2000. MCP 25656, 240, same data as for MCP 25653. MCP 26050, 32, São José dos Ausentes, creek tributary of rio das Antas on road from Ouro Verde to São José dos Ausentes, $c a 1 \mathrm{~km}$ S Parque da Trutas, 2 Jun 2000. MCP 26757, 111, São Gabriel, banhado do arroio Piraí, tributary of rio Vacacaí, 30 Nov 2000. MCP 26780, 1, São Francisco de Paula, arroio dos Veados, 19 Dec 2000. MCP 26907, 8, São Francisco de Paula, rio Contendas, 25 Jan 1998. MCP 26918, 49, São Francisco de Paula, rio Contendas, 2 May 1998. MZUSP 37701, 11, arroio Passo do Carro, road Vacaria, tributary of arroio Quatis, rio Pelotas, 5 Apr 1985. USNM 320237, 7, arroio Água Branca, road from São Joaquim to Bom Jesus. Cnesterodon carnegiei. Brazil. Paraná. CAS 22553, 2, paratypes, rio Paraná at Serrinha, either river or nearby creek, 22 Dec 1908. FMNH 54247, 18, paratypes, rio Iguaçu, Serrinha, 22 Dec 1908. FMNH 56349, 9, Porto União, rio Iguaçu, 27 Dec 1908. MCP 22425, 8, Campo Largo, border with Curitiba, rio Passaúna, 28 Feb 1992. MCP 26030, 5, Araucária, rio Passaúna upstream represa de Ponto Carmo, 16 May 1991. MHNCI 7609, 9/1*, Almirante Tamandaré, rio Passaúna, 11 Oct 1989. USNM 304991, 12/2*, stream in Fazenda Lara Maria, tributary of ribeirão Amola-Faca, near Balsa Nova, 2 May 1989. Cnesterodon decemmaculatus. Argentina. Buenos Aires. AMNH 12350, 10, Buenos Aires, 1933. AMNH 91091, 91 of 182, Buenos Aires, roadside ditches, Punta Lara, just north of la Plata, 12 Nov 1989. AMNH 99900, 5 of 10, Buenos Aires, in pools left by receding river. Punta Lara, along banks of rio de la Plata, 19 Nov 1989. AMNH 99911, 11 of 22, Buenos Aires $15 \mathrm{~km}$ from la Plata, arroyo El Pescado, at ruta 11 bridge, 21 Nov 1989. FMNH 47645, 2, Monte, lake between Buenos Aires and Bahía Blanca, 2 Mar 1909. MLP 9142, 5 of 20, arroyo Napostá Grande, between Tornquist and Estomba, 12 Apr 1983. USNM 152567, 5, Chasmocús, 20 miles S of Buenos Aires, near 
Laguna, 8 Nov 1948. USNM 152568, 12, pond 60 miles S of Buenos Aires, on road to Mar del Plata, 8 Nov 1948. USNM 152569, 9, brackish water of rio Camborombon, 8 Nov 1948. USNM 176108, 12, same data as for AMNH 12350 Mendoza. KU 19193, 10, arroyo Claro, 26 Mar 1976. Río Negro. MLP 5623, 10 of 64, General Fernando Oro. S. Coscarón. Jan. 1950. Santa Fé. MZUSP 46841, 4, Depto 9 de Julio. Ruta nacíonal 98 between Vera and Tostado, 28 Nov 1991. Brazil. Rio Grande do Sul. FMNH 54251, 23, paratypes of Cnesterodon carnegiei, Uruguaiana, 6 Feb 1909. MCP 9649, 3, Dom Pedrito, rio Santa Maria on road BR 293, between Dom Pedrito and Santana do Livramento, 26 Oct 1982. MCP 9793, 3, Bagé, arroio Valente on road BR 153, between Bagé and Aceguá, 25 Oct 1982. MCP 9797, 16, Dom Pedrito, rio Santa Maria on road BR 293, between Dom Pedrito and Santana do Livramento, 26 Oct 1982. MCP 10158, 2, Uruguaiana, arroio Quaraí-Chico at Barra do Quaraí, 16 Nov 1984. MCP 10252, 10, Uruguaiana, first arroio crossing road Uruguaiana-Itaqui, 25 Oct 1982. MCP 10322, 5, creek at km 33 of road BR 153, between Bagé and Aceguá, 25 Oct 1982. MCP 10358, 1, Uruguaiana, creek between barragem do Campus da PUCRS and road BR 472. L. R. Pena, 7 Feb 1985. MCP 10592, 27, creek behind Faculdade de Zootecnia da PUCRS de Uruguaiana, 17 Oct 1985. MCP 10917, 26, Quaraí, rio Garupá on road from Uruguaiana to Quaraí, 22 Jul 1986. MCP 11377, 7, Quaraí, arroio Quaraí-Mirim, road from Quaraí to Alegrete, 12 Nov 1986. MCP 11392, 34, Quaraí, arroio Pai-Passo, road from Alegrete to Santana do Livramento, 12 Nov 1986. MCP 11404, 30/2*, Quaraí, arroio Garupá, between Quaraí-Alegrete, 11 Nov 1986. MCP 17658, 11, Pelotas, old draining channel near Passo do Tabajara, banhado do Pontal da Barra, 5 Jun 1992. MCP 25114, 3, Pedro Osório, creek on road Pedro Osório and Basílio, 20 Nov 1999. MCP 25102, 1, Piratini, arroio Piratini Menor ca $500 \mathrm{~m}$ from road Piratini-Pelotas, 21 Nov 1999. MCP 26741, 2, Santana do Livramento, arroio Ibicuí da Faxina on road BR 158 towards Santana do Livramento, 29 Nov 2000. MCP 26829, 3, Rosário do Sul, sanga da Areia on road RS 640, tributary of rio Santa Maria, 29 Nov 2000. MZUSP 40059, 22, Pelotas, rio Pelotas, 9 May 1967. MZUSP 41022, 12 of 26, same data as for MCP 10917. USNM 285873, 26, same data as for MCP 10917. USNM 309655, + 75, Sarita, small stream at beach, about $12 \mathrm{~km}$ from farol de Sarita, 15 Dec 1979. USNM 309772, 16, Rio Grande, arroio Senandes, where it crosses road between Rio Grande and Cassino, 10 Dec 1979. USNM 309775, 2, Rio Grande, arroio Grande, where crosses under road between Pelotas and Jaguarão, about $1 \mathrm{~km}$ from Rio Grande, 14 Dec 1979. USNM 309776,10, Rio Grande, arroio Bolacha, at crossing of road between Rio Grande and Cassino, 10 Dec 1979. USNM 309779, 43, Rio Grande, north end of banhado do Tigre, actually north of the banhado "third" riacho between fazenda Caçapava and sede da Estação Ecológica do Taim, 13 Dec 1979. USNM 309780, 6, Rio Grande, arroio Pelotas, at bridge crossing along road between Pelotas and Porto Alegre, near Pelotas, 11 Dec 1979. USNM 309787,+100, Rio Grande, north end of banhado do Tigre, riacho between fazenda Caçapava and sede da Estação Ecológica do Taim, 13 Dec 1979. Chile. Valparaíso. UMMZ 212767, 2, Valparaíso, río Marga-Marga, 200 m ca Villa Alemana (introduced), 4 Apr 1963. Uruguay. Cerro Largo. ANSP 67835, 15, arroyo Centurion, Jul 1932. MCP 9985, 16, lake ca $10 \mathrm{~km}$ from río Negro. MCP 10393, 1, Arreria, río Negro, hacienda Arreria. Florida. ANSP 54074, 4, 1932. Montevideo. FMNH 54250, 27, paratypes of Cnesterodon carnegiei, arroyo Miguelete, Montevideo, 17 Feb 1909. KU 22415, 9, 7 Jul 1984. MNHN B-0939, 3, syntypes of Poecilia gracilis (photographs), Montevideo. USNM 87826, 33, Montevideo, 23 Nov 1925. USNM 87827, 3, Montevideo, 15 Nov 1925. Rocha. AMNH 50601, 2, twenty-two kilometres from
Lascano, 10 May 1963. San José. MCP 10397, 47/4*, Sierra Mahoma, 11 Dec 1982. Cnesterodon hypselurus. Brazil. Paraná. MCP 12593, 31/6*, same data as for MCP 22743. MCP 22743, holotype, Jaguariaíva, rio Cilada, bridge of road BR 151, rio Paranapanema drainage, 6 Feb 1988. MCP 22744, 9/2*, collected with the holotype. MCP 22745, 5; MHNCI 5892, 3, paratypes; MCP 12602, 7, Jaguariaíva, rio Lambari, under bridge on road BR 151, rio Paranapanema drainage, 6 Feb 1988. MCP 23326, 10, same data as for MZUEL 1727. MHNCI 5890, 10, collected with the holotype. MZUEL 1600, 14, paratypes. Piraí do Sul, stream affluent of rio Guaricanga, 16 Sep 1998. MZUEL 1727, 10 of 20, Piraí do Sul. creek tributary of rio Guaricanga, 15 May 1999. MZUEL 1728, 122, rio Cilada, fazenda Três Leões, Jaguariaíva, 15 May 1999. UMMZ 215219, 20; USNM 356395, 2, collected with the holotype. Cnesterodon omorgmatos. Brazil. Paraná. MCP 22741, holotype, Pinhão, rio das Torres, rio Iguaçu basin. MCP 22742, 21 / 4*; MHNCI 7657, 22; USNM 356394, 4, collected with the holotype. Cnesterodon raddai. Paraguay. Misiones, UMMZ 207503, $12 / 1^{*}$, small stream at bridge on dirt road to Ayolas ( ca $51.2 \mathrm{~km} \mathrm{~S}$ of San Patricio), ca $2 \mathrm{~km}$ ENE of Ayolas; río Paraná drainage. $27^{\circ} 22^{\prime} 12^{\prime \prime S}$ 56²3'12"W, 27 Aug 1979. Neembucu. UMMZ 207748, 30/2* of 102 , small pool on S side of dirt road between San Ignacio and Pilar, ca $114 \mathrm{~km}$ WNW of San Ignacio (ca $8 \mathrm{~km}$ WNW of San Juan) 264’24"S 5755'12"W, 2 Set 1979. Cnesterodon septentrionalis. Brazil. Mato Grosso. MZUSP 41370, 25/1*; MZUSP 41371, 8, paratypes, Alto Araguaia, swamp near córrego do Rancho fountainhead, 8 Mar 1989. MZUSP 69684, 60 of 159, Alto Araguaia, córrego Jaguatirica, $496.46 \mathrm{~km}$ from ferrovia Ferronorte, 17 May 2001. MZUSP 69685, 40 of 85, Alto Araguaia, córrego do Mosquito, $476.3 \mathrm{~km}$ from ferrovia Ferronorte, 19 May 2001. MZUSP 69686, 22 of 45, Alto Araguaia, córrego do Sapinho, $474.64 \mathrm{~km}$ from ferrovia Ferronorte, 19 May 2001. MZUSP 69687, 21/4* of 42, Alto Araguaia, ribeirão do Sapo, $464.04 \mathrm{~km}$ from ferrovia Ferronorte, 19 May 2001.

\section{Acknowledgements}

For loan of specimens I am deeply indebted to Anne-Marie Hine (BMNH), Barbara Brown (AMNH), Barry Chernoff (FMNH), Carl Ferraris (CAS), David Catania (CAS), Edward Wiley (KU), Hugo López (MLP), James Maclaine (BMNH), José Pezzi da Silva (MCP), José Lima Figueiredo (MZUSP), Kate Shaw (KU), Mary Anne Rogers (FMNH), Oscar Shibatta (UEL), Osvaldo Oyakawa (MZUSP), Richard Vari (USNM), Scott Schaefer (AMNH), Susan Jewett (USNM), Vinícius Abilhôa (MHNCI), John Lundberg (ANSP), and William Fink (UMMZ). I am grateful to José Pezzi da Silva for the map and curatorial help in MCP. I thank Michel Jégu (MNHN) and Roberto Reis (MCP) for providing photographs of the syntypes of Poecilia gracilis. The manuscript benefited from reviews by Carlos Lucena (MCP), Lynne Parenti (USNM), Roberto Reis (MCP), and a anonymous reviewer. Edson Pereira (MCP) photographed the specimens. This study was developed during a doctoral programme at the Pontifícia Universidade Católica do Rio Grande do Sul (PUCRS) and was supported by the Universidade do Tocantins (UNITINS), the Universidade Federal do Tocantins (UFT), and the Fundação Coordenação de Aperfeiçoamento de Pessoal de Nível Superior (CAPES-PICDT doctoral fellowship). 


\section{Literature Cited}

Boulenger, G. A. 1889. Descriptions of a new snake and two new fishes obtained by Dr. H. von Ihering in Brazil. Annals and Magazine of Natural History (Ser. 6), 4(22): 265267.

Cuvier, G. \& A. Valenciennes. 1846. Histoire naturelle des poissons. Tome dix-huitième. Suite du livre dix-huitième. Cyprinoïdes. Livre dix-neuvième. Des Ésoces ou Lucioïdes. Hist. Nat. Poiss. v. 18: i-xix + 2 pp. $+1-505+2$ pp., Pls. 520-553.

Garman, S. 1895. The Cyprinodonts. Memoirs of the Museum of Comparative Zoology, 19: 1-179.

Garman, S. 1896. Cross fertilization and sexual rights and lefts among vertebrates. American Naturalist, 30: 232.

Gosline, W. A. 1949. The sensory canals of the head in some Cyprinodont fishes, with particular reference to the genus Fundulus. Occasional Papers of the Natural History Museum, University of Kansas, 519: 1-17.

Günther, A. 1866. Catalogue of fishes in the British Museum. Catalogue of the Physostomi, containing the families Salmonidae, Percopsidae, Galaxidae, Mormyridae, Gymnarchidae, Esocidae, Umbridae, Scombresocidae, Cyprinodontidae, in the collection of the British Museum, Cat. Fishes v. 6: i-Xv +1-368.

Haseman, J. D. 1911. Some new species of fishes from the Rio Iguaçu. Annals of the Carnegie Museum, 7(3/4): 374-387.

Hensel, R. 1868. Beiträge zur Kenntnis der Wirbeltiere Sudbrasiliens. Archives fur Naturgeschichte, 34(2): 323375.

Jenyns, L. 1842. Fish. Pp. 115-117. In: Jenyns, L. The zoology of the voyage of H. M. S. Beagle, under the command of Captain Fitzroy, R. N., during the years 1832 to 1836 . London. Smith, Elder, and Co. Issued in 4 parts. Fish, Voyage Beagle: i-xvi + 1-172, Pls. 1-29.

Langer, W. F. 1913. Beiträge zur Morphologie der viviparen Cyprinodontiden. Morphologisches Jahrbuch, 47(1-2): 193-307.

Leviton, A. E., R. H. Gibbs Jr., E. Heal \& C. E. Dawson. 1985. Standards in Herpetology and Ichthyology: Part I. Standard Symbolic for Institutional Resource Collections in Herpetology and Ichthyology. Copeia, 1985: 802-832.

Lucinda, P. H. F. 2003. Family Poeciliidae. Pp. 555-581. In: R. E. Reis; S. O. Kullander \& C. J. Ferraris Jr. (Eds.). Check list of the freshwater fishes of South and Central America. Porto Alegre, Edipucrs, i-xi +1-729p.

Lucinda, P. H. F. \& J. C. Garavello. 2001. Two new species of Cnesterodon Garman, 1895 (Cyprinodontiformes, Poeciliidae) from the upper Rio Paraná drainage. Comunicações do Museu de Ciências e Tecnologia da PUCRS, Série Zoologia, 13(2): 119-138.
Lucinda, P. H. F. \& R. E. Reis. 2005. Systematics of the subfamily Poeciliinae Bonaparte (Cyprinodontiformes: Poeciliidae). Neotropical Ichthyology, 3(1):1-60.

Meyer, M. K \& V. Etzel. 2001. Description of Cnesterodon raddai sp. n. from a swamp near Resistencia, Rio Paraná basin, Argentina (Teleostei: Cyprinodontiformes: Poeciliidae). Zoologische Abhandlungen Staatliches Museum für Tierkunde Dresden, 51(17): 247-252.

Parenti, L. R. 1981. A phylogenetic and biogeographical analysis of Cyprinodontiform fishes (Teleostei, Atherinomorpha). Bulletin of the American Museum of Natural History, 168(4): 341-557.

Phillipi, E. 1906. Kurzer Beitrag zur Kenntniss der Teleostiergenera Glaridichthys Garman und Cnesterodon Garman (Familie Cyprinodontidae s. Poeciliidae). Sonderabdruck aus den Sitzungsberichten der Gesellschaft Naturforschender Freunde, 8: 229-232.

Phillipi, E. 1908. Fortpflanzungsgeschichte der viviparen Teleosteer. Glaridichthys januarius und G. decemmaculatus in ihrem Einfluss auf Lebensweise, makroskopische und mikroskopische Anatomie. Zoologisches Jahrbuch, 27: 1-94.

Regan, C. T. 1913. A revision of the Cyprinodont fishes of the subfamily Poeciliinae. Proceedings of the Zoological Society, London, 5: 977-1019.

Reis, R. E. 1996. "LMDis” software - version 1.0.

Reis, R. E. \& N. F. Fontoura. 1993. "Datax" software - version 4.2.

Rohlf, F. J. 2003. “TpsDig” software - version 1.37.

Rosa, R. S. \& W. J. E. M. Costa. 1993. Systematic revision of the genus Cnesterodon (Cyprinodontiformes, Poeciliidae) with the description of two new species from Brazil. Copeia, 1993: 696-708.

Rosen, D. E. \& J. R. Mendelson. 1960. The sensory canals of head in Poeciliid fishes (Cyprinodontiformes), with reference to dentitional types. Copeia, 1960: 203-210.

Rosen, D. E. \& M. Gordon. 1953. Functional anatomy and evolution of male genitalia in Poeciliid fishes. Zoologica, 38(1):1-47.

Rosen, D. E. \& R. M. Bailey. 1963. The Poeciliid fishes (Cyprinodontiformes) their structure, zoogeography and systematics. Bulletin of the American Museum of Natural History, 126(1): 1-176.

Taylor, W. R. \& G. C. Van Dyke. 1985. Revised procedures for staining and clearing small fishes and other vertebrates for bone and cartilage study. Cybium, 9: 107-119.

Submitted May 2004 Accepted January 2005 